\title{
Innovative Course of Descriptive Geometry
}

\author{
Irina Sergeyeva ${ }^{1,}$, , Yelena Korotkova ${ }^{1}$, Edward Kolos $^{1}$, and Christian Martinez ${ }^{1}$ \\ ${ }^{1}$ Far Eastern Federal University, 10 Ayax Settlement, the Russkiy Island, the City of Vladivostok, \\ Russia
}

\begin{abstract}
The paper deals with the solution to the problems of insufficient preparation of applicants for the study of the Descriptive Geometry course offered to them in the university during their first year of education in such programs of study as Mechanical Engineering, Automation of Technological Production Processes, Mechatronics and Robotics, as well as Oil and Gas Engineering. The relevance, efficiency and advantages of an innovative course using AutoCAD and new teaching material for independent work of both Russian and foreign students were evaluated. Algorithms for the construction of 3D models of intersecting tangent surfaces and surfaces with a common inscribed sphere were developed to control individual tasks. The tasks of two-level complexity of constructing projections of parts with surfaces intersecting along curved lines and their 3D models with sections for monitoring the retained knowledge of students on the subject were developed and the effectiveness of their application was evaluated.
\end{abstract}

The modern social situation puts forward requirements for the education system aimed at the development and formation of a personality capable of continuous learning, changing the ways of their educational, professional and social activities. [1].

One of the many problematic situations in education is the contradiction between the high requirements of employers for the professional training of engineers and the capabilities of universities to provide such a level of training to their graduates.

Descriptive Geometry is an important basic discipline for the study of many technical subjects learnt by students of technical programs of study. Its use is necessary in the design of complex surfaces of technical shapes in many areas of technology. However, the basic training of high school graduates in geometry and drawing does not correspond to the level of training required at higher school. The quality of studying geometry is not sufficient in all schools, and drawing is excluded from the compulsory school curriculum. As a result, in such programs of study as mechanical engineering, applicants enter universities with a low passing score and do not master the subject at the proper level.

For foreign students enrolled in institutions of higher education, where education is conducted in Russian, the main obstacle to the study of Descriptive Geometry is the language barrier [2]. Before entering the university, they study Russian and undergo basic training in drawing, which is not enough to study the subject, because it is also necessary to know the terminology of Descriptive Geometry.

\footnotetext{
*Corresponding author: irina7349@mail.ru
} 
To assess and improve the effectiveness of the course, the authors set the following goals:

1. To define the concept of innovativeness, to define the characteristics of an innovative author's course in the AutoCAD graphic environment and their implementation in the learning process, as well as course components.

2. To assess the relevance, efficiency and advantages of an innovative electronic course of Descriptive Geometry in the AutoCAD environment and methodological material for independent work of the Russian and foreign students of technical programs of study.

3. To develop a technique for constructing 3D models with inscribed and tangent surfaces to control the solution of problems of Descriptive Geometry in the AutoCAD environment.

4. To develop two-level tasks of parts with intersecting surfaces along curved lines to test the retained knowledge of Descriptive Geometry.

5. To evaluate the effectiveness of experimental training according to the proposed methodology with the Russian-speaking and foreign first-year students of different degrees of training, engaged in such programs of study as Mechanical Engineering, Mechatronics and Robotics, Automation of Technological Production Processes and Oil and Gas Engineering.

The publications of other authors who use AutoCAD when teaching Descriptive Geometry and engineering graphics to their students, were studied. As a lecture material, some authors use presentations, other ones use video lectures, most often with prepared visualization of graphic images. When giving lectures, special emphasis is placed on the effective use of technical means of presenting information with thoughtful visualization of graphic images on multimedia equipment. Students learn Auto-CAD using video tutorials and then make drawings "in an automated way" [3]. Teachers use 3D modeling, which enables students to fully represent the object under study [4]. When constructing three-dimensional models of the given surfaces, the intersecting line is obtained automatically in accordance with the algorithms of computer graphics ... [5]. Thus, students carry out the construction of 3D models for self-control of graphic tasks.

As a result of the review of literature, it becomes obvious that specialists working in this area use such advanced computer technologies as visual video lessons, multimedia equipment, 3D models for visualizing graphic objects and self-checking the results of constructing lines of intersection of surfaces. However, the capabilities and advantages of AutoCAD are not used to the full extent, in particular, for placing and demonstrating lecture material on the subject, developing a methodology for constructing 3D models of intersecting surfaces, determining control points and visibility of the surfaces intersecting line, which is the essence of the innovative approach.

The concept of innovativeness (from the Latin word innovation) means any change, renewal, innovation and has two aspects - innovation and implementation of this innovation in a certain process [6].

The course is called innovative, since in the learning process such characteristics as visibility are realized, since the graphic information in AutoCAD is represented by clear figures, and to improve visualization, small constructions are easily enlarged, which is important for the specifics of the subject. The course is effective and intensive, since the time for the presentation of lecture material is significantly reduced, and the solution of problems in practice and in individual homework (IHW) is attended by high accuracy. Some of the main characteristics of the course are rationality, usefulness and motivation, since students independently study AutoCAD and effectively solve problems in this environment, they develop spatial imagination, logical and creative thinking in the process of comparing different algorithms for using AutoCAD commands and choosing more rational algorithms in $2 \mathrm{D}$ and $3 \mathrm{D}$ constructions. The course also assumes the development of motor skills in 
students in the process of working with the mouse pointing device. The course contributes to the development of students' motivation to engage in collective scientific work and make reports at scientific conferences. Therefore, it is implemented as the development of creative process. Due to the characteristic of adaptability, it can be adapted to the level of students, changing the pace of explanations, or introduce constructions in the course of practical classes, while problem solving is dynamic. The course can be combined in the process of both classroom and distance learning, and in the process of switching from one type of training to another, neither instructor nor students need special adaptation. Finally, the course provides students with feedback in the form of review works on each topic that can be completed in the electronic environment, and makes it possible for the instructor to edit test options quickly. Table 1 presents the main characteristics of the innovative author's course and their implementation in the process of teaching the Descriptive Geometry course for the $1^{\text {st }}$ year university bachelor students, engaged in such programs of study as Mechanical Engineering, Automation of Technological Production Processes, Mechatronics and Robotics, as well as Oil and Gas Engineering.

The following research methods were used in the work - observational, descriptive, analytical and comparative. The observational method was used during consultations with students and in determining the level of their knowledge. The analytical method was used in the development of the methodology for the construction of 3D models of intersecting surfaces. The descriptive method was used in the process of describing tables, and the comparative method was used when comparing the results of IHW with 3D models, during exam and comparison of the students' test results.

Table 1. Characteristics of innovative author's course and their implementation in the process of learning

\begin{tabular}{|c|c|c|c|c|c|c|}
\hline $\begin{array}{l}\text { Properties } \\
\text { of innova- } \\
\text { tive course }\end{array}$ & Visibility & $\begin{array}{l}\text { Efficiency, } \\
\text { intensity }\end{array}$ & $\begin{array}{c}\text { Rationality, } \\
\text { motivation, } \\
\text { usefulness }\end{array}$ & $\begin{array}{c}\text { Adapta- } \\
\text { bility }\end{array}$ & $\begin{array}{c}\text { Compati- } \\
\text { bility with } \\
\text { both class- } \\
\text { room and } \\
\text { distance } \\
\text { learning }\end{array}$ & Feedback \\
\hline $\begin{array}{l}\text { Implemen- } \\
\text { tation of } \\
\text { the charac- } \\
\text { teristics of } \\
\text { innovative } \\
\text { author's } \\
\text { course in } \\
\text { the process } \\
\text { of learning }\end{array}$ & $\begin{array}{l}\text { 1. clarity } \\
\text { of presen- } \\
\text { tation of } \\
\text { graphic } \\
\text { infor- } \\
\text { mation in } \\
\text { Auto- } \\
\text { CAD; } \\
2 . \quad \text { im- } \\
\text { prove- } \\
\text { ment of } \\
\text { visualiza- } \\
\text { tion by } \\
\text { increasing } \\
\text { small } \\
\text { construc- } \\
\text { tions; }\end{array}$ & $\begin{array}{l}\text { 1. reduc- } \\
\text { tion of } \\
\text { time for } \\
\text { presenta- } \\
\text { tion of } \\
\text { lecture } \\
\text { material; } \\
2 \text {. high } \\
\text { accuracy of } \\
\text { solving } \\
\text { problems } \\
\text { in practice } \\
\text { and in the } \\
\text { IHW; }\end{array}$ & $\begin{array}{l}\text { 1. independ- } \\
\text { ent study of } \\
\text { AutoCAD by } \\
\text { students; } \\
2 . \text { develop- } \\
\text { ment of spa- } \\
\text { tial imagina- } \\
\text { tion, logical } \\
\text { and creative } \\
\text { thinking; } \\
3 \text {. rationali- } \\
\text { zation of } \\
\text { algorithms in } \\
2 \mathrm{D} \text { and } 3 \mathrm{D} \\
\text { construc- } \\
\text { tions; } \\
4 . \text { motivation } \\
\text { for the per- } \\
\text { formance of } \\
\text { scientific } \\
\text { work; }\end{array}$ & $\begin{array}{l}\text { 1. dyna- } \\
\text { mism of } \\
\text { problems } \\
\text { solution; } \\
\text { 2. adapt- } \\
\text { ability of } \\
\text { the } \\
\text { course to } \\
\text { the level } \\
\text { of stu- } \\
\text { dents; }\end{array}$ & $\begin{array}{l}\text { no adapta- } \\
\text { tion period } \\
\text { during the } \\
\text { change } \\
\text { from class- } \\
\text { room type } \\
\text { of training } \\
\text { to distance } \\
\text { one for } \\
\text { both the } \\
\text { instructor } \\
\text { and the } \\
\text { students; }\end{array}$ & $\begin{array}{l}\text { 1. imple- } \\
\text { mentation } \\
\text { of review } \\
\text { works on } \\
\text { each } \\
\text { topic in } \\
\text { the elec- } \\
\text { tronic } \\
\text { environ- } \\
\text { ment; } \\
\text { 2. Opera- } \\
\text { tive edit- } \\
\text { ing of test } \\
\text { options; }\end{array}$ \\
\hline
\end{tabular}


The components of the innovative electronic course in Descriptive Geometry, developed by the author, are as follows: a) lecture material in the AutoCAD environment based on the textbook [7] and the tutorial on Descriptive Geometry [8]; b) a workbook for the instructor, compiled according to a similar principle; c) individual homework (IHW) in the AutoCAD environment; and d) presentations and demonstrations on the Surface topic.

In the author's electronic course of Descriptive Geometry, graphic material is placed in a dynamic sequence in layers. The AutoCAD environment is used as an endless visual electronic board, where it is possible to put any additional graphic and text information and insert information from other sources during the lecture. Any explanation is easily repeated, it is explained either by turning on/off layers with ready-made material, or by additional constructions. Due to its visibility, dynamism and the above listed additional effects, such a course has a significant advantage over presentations or video material, and its 3D models play the role of reference for students, that is, such models that are exemplary, ideal, approximate, standard (reference model, master model), on the basis of which the tasks in the IHW, solved by the students, are compared with the reference 3D models [9].

The instructor's workbook is compiled according to a similar principle: problem solutions are dynamic, the course can be adapted to the level of students by changing the pace of explanations, or make constructions during practical lessons. The purpose of the workbook is the acquisition of skills for performing the IHW and preparing trainees for the semester exam. Some of the tasks are included in the workbook to consolidate the theoretical material in practical classes, the other ones are intended for independent solution and selfcontrol of knowledge. The workbook of the students and the instructor has the same electronic graphic base. Only the statements of problems are included in the students' workbook. They print it out and solve it on paper in the traditional way. The need to copy the statements of problems from the board has been eliminated, which saves the time, increases the accuracy of graphic solutions and reduces the time for checking their results.

One more additional component of the innovative course is the Russian-English dictionary of Descriptive Geometry terms, developed by senior students. In the 2020-2021 academic year, foreign students used this Russian-English dictionary of Descriptive Geometry terms and their experience in consulting with simultaneous interpreting with foreign students who had less training. In this context, the experience of student D. Amirul was used, who proposed an approach that would improve the perception of studying the course of descriptive geometry for foreign students [10].

Students receive IHW with the introduced statement and solve it in AutoCAD, using clear color constructions and their distribution among layers, which increases the accuracy of solutions, significantly saves time and eliminates the routine work of entering coordinates and lines. When giving IHW, the instructor performs an example of the solution and design of a sample option or difficult fragments of other options in the AutoCAD environment, which cannot be shown on a traditional board. The instructor displays the control of any student's IHW on the screen, which makes it possible for the whole group to notice, understand and correct their own mistakes, significantly increases the quality of the IDS by students and reduces the total time of control.

In addition, in the period from October to December 2020, additional lecture and practical material was developed, intended for the independent work of the low-performing Russian and foreign students, based on the reviewed lectures and a workbook. Explanations with theoretical justification were added to the materials of lectures and workbooks, placed in layers corresponding to the sequence of presentation of the material. In this form, students learned the theory and construction algorithm better. The options for foreign students were supplemented by the translation into English, which was included together with the Russian text. 
Fig. 1 shows the first step of the problem solution in layer 1. Fig. 2 shows the second step of the problem solution in layer 2. The effectiveness of the use of the new material was tested on the Russian and foreign students. The instructor included layers with text corresponding to the constructions without any explanations. At the same time, a student from Afghanistan, T. Sadek, and the student Ch. Martinez did not have any questions, and no additional translation was required. Then, this material was given to low-performing students for independent work. Both Russian and foreign students began to master the educational material faster. Ch. Martinez completed and defended the IHW option of the third level of complexity. The advantages of the developed material include the ability to assimilate lecture and practical material more effectively for the low-performing Russian and foreign students.

\section{Building a plane normal to a given plane}

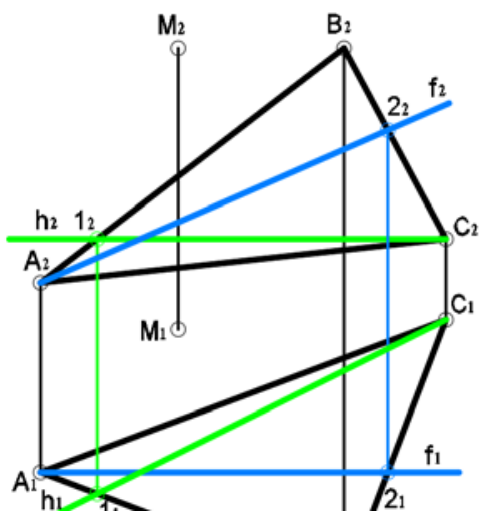

We set the frontal line and the horizontal line in the plane

Fig. 1. First step of problem solution in layer 1.

\section{Building a plane normal to a given plane}

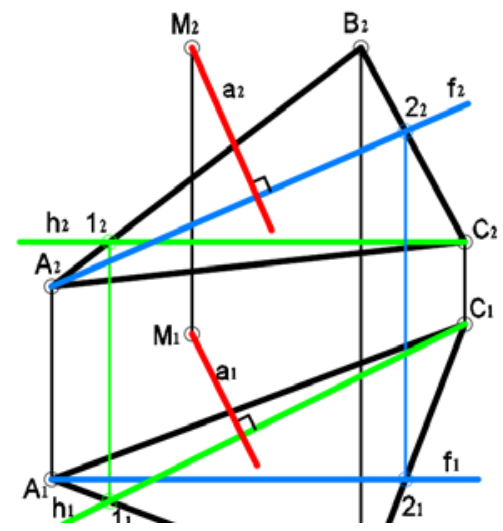

We set the frontal line and the horizontal line in the plane Using the theorem on the projection of a right angle, we lower the perpendiculaer to the plane

Fig. 2. Second step of problem solution in layer 2.

Studies on the effectiveness of the experimental technique using this material for the Russian students were carried out in three groups (Table 2). This teaching material helped to optimize classes and improve performance in groups according to their program of study 
from December 2020 to February 2021. Table 2 shows the programs of study in the experimental groups of students, the time the teaching aids were used, the number of students in the groups and the percentage of their progress. The result of the study showed high efficiency and expediency of the use of the developed material.

Table 2. Information on the use of teaching aids (\%).

\begin{tabular}{|l|l|l|l|}
\hline Program of study & $\begin{array}{l}\text { Use of teaching } \\
\text { aids }\end{array}$ & $\begin{array}{l}\text { Number of students } \\
\text { in the group \% }\end{array}$ & $\begin{array}{l}\text { Number of } \\
\text { achievers \% }\end{array}$ \\
\hline $\begin{array}{l}\text { Automation of Technological Produc- } \\
\text { tion Processes }\end{array}$ & $\begin{array}{l}\text { Used for } 1.5 \\
\text { months }\end{array}$ & 100 & 100 \\
\hline Mechatronics and Robotics & Used for 2 weeks & 100 & 92 \\
\hline Mechanical Engineering & No use & 100 & 80 \\
\hline
\end{tabular}

Spatial thinking, like any other human ability, needs to be developed. With the help of three-dimensional modeling in the environment of graphic packages, the task of visual representation of geometric objects is simplified greatly, which is one of its many advantages [11].

Students use models of intersecting surfaces for self-control of IHW using command Unite to construct a surfaces intersecting line [9, 12]. In December 2020, a methodology was developed for constructing 3D models of intersecting surfaces, with which students had some difficulties. The model of an elliptical cone and a cylinder tangent to it is performed according to a certain algorithm. First, the construction of flat images of the base, the generatrix of the cone and the tangent to it at point A of the projection of the cylinder are performed using object snap (Fig. 3) [12]. The generatrix is lengthened up to the continuation of the vertical segment SP. Point S is the vertex of the conical surface. Then a 3D rotation of the generatrix BS and the tangent circle to the frontal position is performed, after the transfer of the center of the tangent circle to point D (Fig. 4), the cylinder is displaced from it using command Displace [12]. To build a cone model, command Loft is used, specifying the projection of the base of the cone and the coordinates of the vertex, and then a piecewise linear surface is selected (see Fig. 4). To draw the surfaces intersecting line with a contrasting color, command Unite is run (Fig. 4).

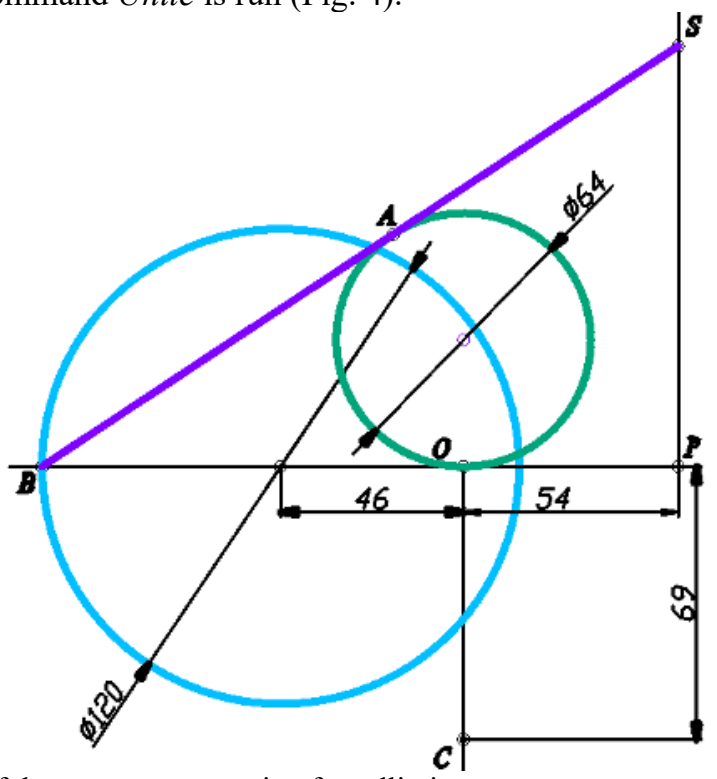

Fig. 3. Construction of the tangent generatrix of an elliptic cone. 

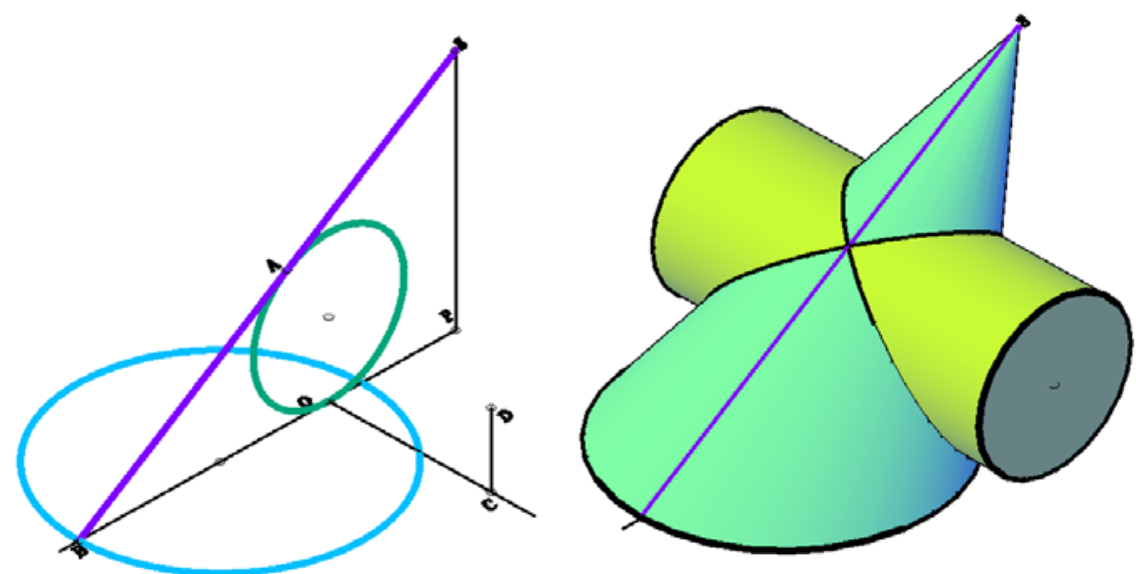

Fig. 4. Result of the use of commands Loft and Unite when performing 3D rotation.

An example of two surfaces with a common inscribed sphere is shown in Fig. 5. The generatrices of the cylinder and of the cone and the tangent projection of the sphere in the form of a circle were built in the horizontal plane, a model of the sphere with the same radius was built in the center of the inscribed circle, then a 3D rotation was performed. The cone model was carried out by rotating a closed contour. To draw the surfaces intersecting line, command Unite was run. The result of construction in Fig. 5 corresponds to Monge theorem [7]. The results of the studies helped the students to perform 3D control of the IHW solution and improve the group performance.
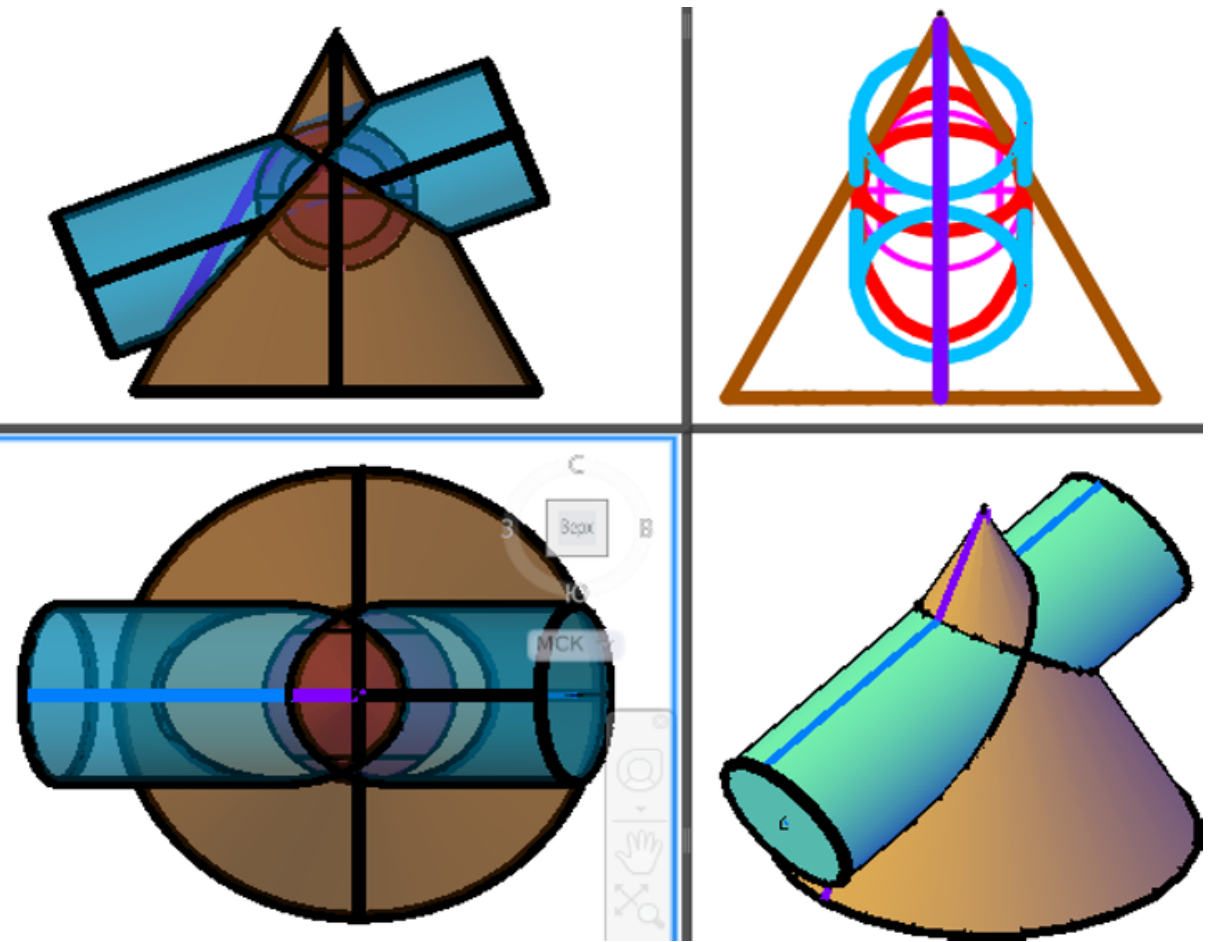

Fig. 5. Intersection of surfaces with a common inscribed sphere. 
In March 2021, to test the retained knowledge of Descriptive Geometry, tasks were developed for parts with surfaces intersecting along curved lines of a two-level degree of complexity - without internal intersection of surfaces and with internal intersection. To construct curved lines, students used the method of cutting planes [13]. The tasks of the first level of difficulty were compiled for students with gaps in the Descriptive Geometry knowledge. As illustrations, several examples of surfaces of revolution in 3D format were proposed - a cylinder, a truncated cone and a sphere. To construct holes in them, prisms displaced from trapezoids, squares and triangles, were proposed. Control over the fulfillment of tasks was carried out using 3D models of parts. The construction of models was carried out by the achievers of Automation of Technological Production Processes groups according to the method described for models of complex parts [14], which appeared to be a creative task for them.

In groups of students majoring in Mechanical Engineering and Automation of Technological Production Processes, the test was carried out to check the retained knowledge on the Intersection of Surfaces topic (Table 3). Table 3 shows programs of study, total number of students who performed the test in each group and the results of control.

Table 3. Retained knowledge test information.

\begin{tabular}{|c|c|c|c|c|c|}
\hline Program of Study & $\begin{array}{c}\text { Total } \\
\text { number } \\
\text { of stu- } \\
\text { dents } \\
\text { who per- } \\
\text { formed } \\
\text { the test }\end{array}$ & $\begin{array}{l}\text { Number of } \\
\text { students } \\
\text { who com- } \\
\text { pleted the } \\
\text { task of the } \\
1^{\text {st }} \text { level of } \\
\text { complexity }\end{array}$ & $\begin{array}{l}\text { Number of } \\
\text { students who } \\
\text { completed the } \\
\text { task of the } 2^{\text {nd }} \\
\text { level of com- } \\
\text { plexity }\end{array}$ & $\begin{array}{l}\text { Number of } \\
\text { students } \\
\text { who re- } \\
\text { ceived } \\
\text { excellent } \\
\text { marks }\end{array}$ & $\begin{array}{l}\text { Number } \\
\text { of stu- } \\
\text { dents who } \\
\text { received } \\
\text { good } \\
\text { marks }\end{array}$ \\
\hline $\begin{array}{l}\text { Automation of Techno- } \\
\text { logical Production Pro- } \\
\text { cesses }\end{array}$ & 18 & 5 & 13 & 11 & 7 \\
\hline Mechanical Engineering & 19 & 6 & 13 & 7 & 12 \\
\hline
\end{tabular}

The $1^{\text {st }}$ year students, both Russian and foreign, with varying degrees of preparation successfully coped with the proposed tasks. In the group of Automation of Technological Production Processes, out of 18 students, 5 students completed the task of the first level of complexity, and 13 students - of the second one. 11 tasks were rated excellent, 7 - good. In the group of Mechanical Engineering, 6 out of 19 students performed the task of the first level of complexity, 13 - of the second one. 7 tasks were rated excellent, 12 -good. 


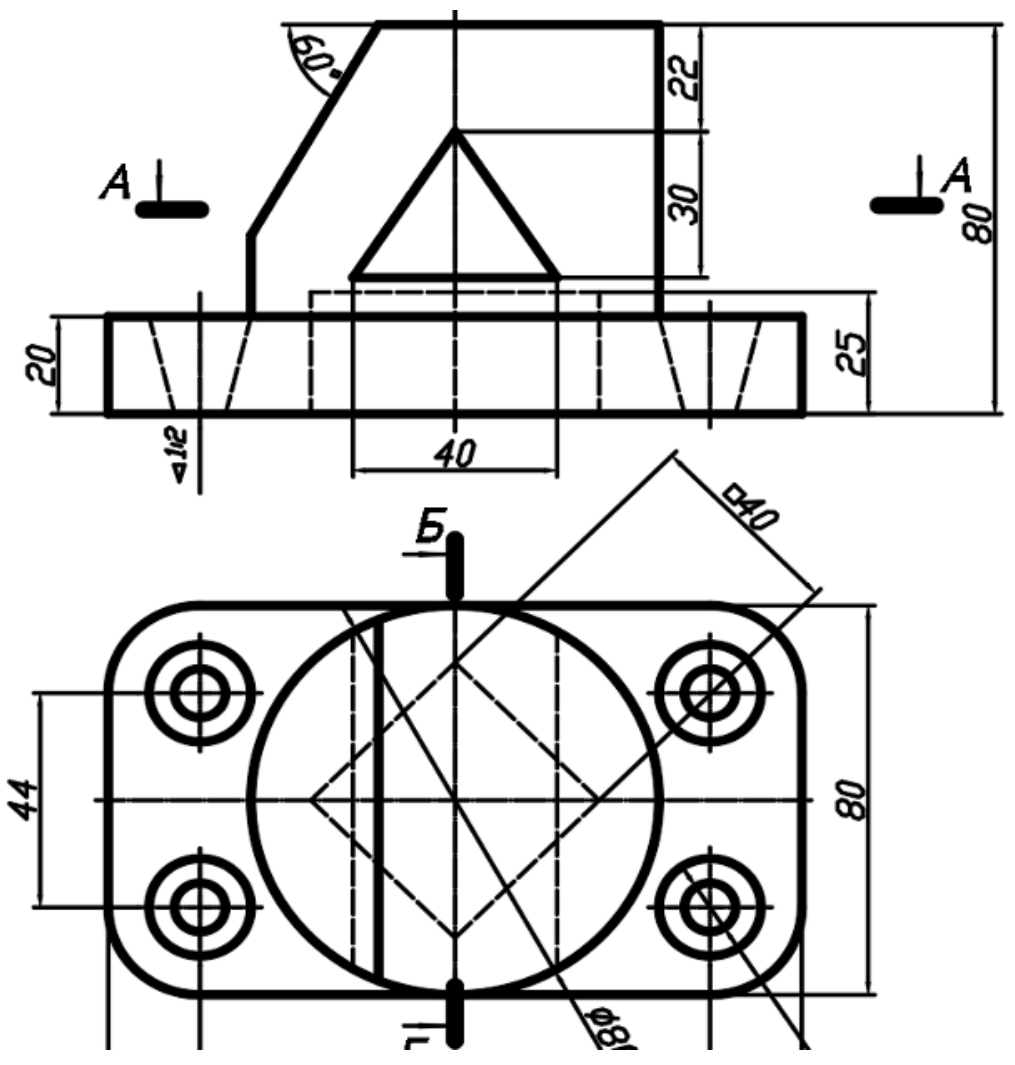

Fig. 6. Fragment of the task of the first level of complexity.

The task of the first level of complexity is shown in Fig. 6. Control of tasks using 3D models of parts with horizontal and longitudinal sections [12] of two levels of complexity is shown in Fig. 7.
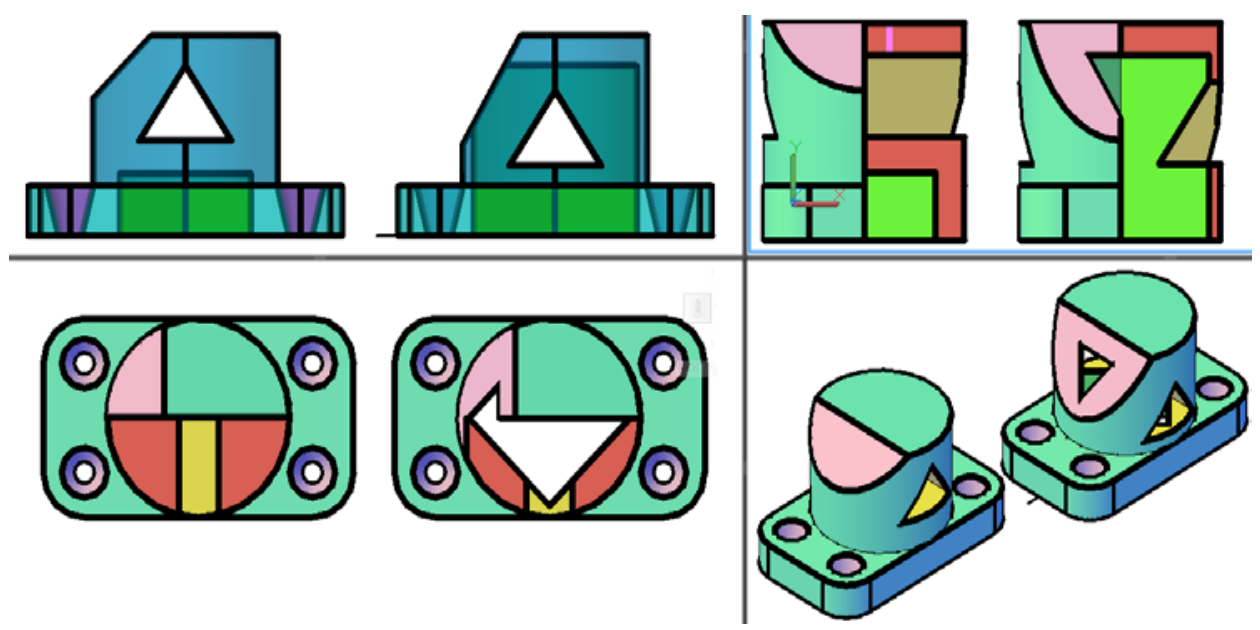

Fig. 7. Control of tasks using 3D models of parts. 


\section{Conclusion}

To determine the novelty of the author's course, the concept of innovativeness was developed and its main characteristics, implemented in the process of learning, and components were determined. The characteristics of the innovative course are visibility, efficiency and intensity, rationality, the formation of students' motivation to engage in scientific work and the undoubted usefulness of the course, as well as its adaptability, compatibility with classroom and distance learning and feedback. The study clearly traces the implementation of the characteristics of an innovative course in the process of teaching Descriptive Geometry to the students, as well as its advantages when switching from classroom to distance learning and vice versa.

The components of the innovative course are as follows: lecture material in the AutoCAD environment based on the textbook and the tutorial on Descriptive Geometry; a workbook for the instructor with tasks adapted to the level of the trainees; individual homework (IHW) in the AutoCAD environment, as well as presentations and demonstrations on the Surface topic.

The data of experimental training confirmed the high efficiency of the teaching aids for independent work of both Russian and foreign university bachelor students majoring in Automation of Technological Production Processes, Mechatronics and Robotics, Mechanical Engineering.

A technique for constructing 3D models with inscribed and tangential surfaces to control the solution of problems in the Descriptive Geometry course was developed and its application was substantiated for the development of spatial imagination and control of students' IHW. Also, two-level tasks of parts with the intersection of surfaces along curved lines were developed to check the Descriptive Geometry retained knowledge and 3D models with given sections to control the performance of tasks. Part models were developed by the Automation of Technological Production Processes achievers. It is recommended to use the construction of models of similar parts to develop the creative abilities of students.

This innovative course can and should be improved. The author, I.V. Sergeyeva, developed and prepared for publication a textbook Intersection of Surfaces, which described the method of constructing 3D models of tangent surfaces with a common inscribed sphere. In the future, to improve the quality of students' performance and optimize the learning process for the Descriptive Geometry course, it is necessary to develop new versions of the IHW of the first level of complexity for low-performing students and the third level of complexity for advanced students, including presentations of the IHW on the Intersection of Surfaces topic with the text in Russian and in English for foreign students and additional options for the tasks concerning parts with surfaces intersecting along curved lines.

\section{References}

1. Ye.A. Sorokoumova, Educational Psychology: A Short Course (SPb Peter, 2009)

2. S.P. Zaytseva, M.P. Stadik, Innovative Technologies in Education, 78,79 (2017)

3. T.N. Bazenkov, N.S. Vinnik, N.S. Zhiteneva, Innovative Technologies in Engineering Graphics, 74-76 (2014)

4. Z.N. Usalevich, V.P. Usalevich, Innovative Technologies in Engineering Graphics: Problems and Prospectives, 251-255 (2020)

5. N.V. Novik, Society: Sociology, Psychology, Pedagogics, 88-90 (2016 No. 8)

6. Word Card / Interpretation / Reference. [Electronic Resource] URL: https://kartaslov.ru (viewed on 10.04.21). 
7. L.V. But, Ye.O. Gritskevich, S.I. Davydov, M.I. Kaulin, I.P. Lazareva, Yu.N. Pavlyuchenko, I.M. Salomatina, Descriptive Geometry: A Short Course (Vladivostok Far Eastern State Technical University, 2006)

8. S.A. Frolov, Descriptive Geometry: A Tutorial (Moscow INFRA-M, 2007)

9. I.V. Sergeyeva, A.Ye. Zhuravlyov, G.M. Karpov, Prospectives for the Development of Information Technology, 117-121 (2013)

10. D.B.S. Amirul. K.I. Runtov, A.S. Bespalov, I.V. Sergeyeva. [Electronic Resource] URL: http://www.nauchforum.ru/archive/MNF_tech/3(43).pdf

11. Kh. Davletyarov, I.G. Borisenko, Free Prospectus-2016, 4 (2016)

12. N.N. Polischuk, AutoCAD 2017 Tutorial (Saint Petersburg BKhV-Peterburg, 2017)

13. A.A. Chekmaryov, Descriptive Geometry and Drawing: A Tutorial (Moscow VLADOS, 2005)

14. I.V. Sergeyeva, T.V. Shustikova, V.A. Kurlova, Topical Issues of Theory and Practice of Scientific Research Development, 35-43 (2019) 